\title{
SOMATIC SEGREGATION OF THE SPECTACLE PATTERN ON POTATO TUBERS
}

\author{
N. W. SIMMONDS \\ John Innes Institute, Hertford
}

\section{INTRODUCTION}

Received 2I.xi. $6_{4}$

THIs paper is concerned with the spontaneous alteration of a tuber colour pattern which is inherited vegetatively and the expression (or suppression) of which is apparently related to the layered structure of the apical meristem.

\section{MATERIALS AND METHODS}

The stocks used were all South American tetraploid potatoes $(2 n=48$, Andigena Group). The four clones most used were: 62/I9I (C.P.C. 3048 from Peru); 62/23 I (C.P.C. $354 / 2$ from Bolivia); 62/232 (C.P.C. 2774 from Bolivia); 62/235 (C.P.C. $328 \mathrm{I}$ from Chile). 62/23I was a newly raised seedling descended from the original Bolivian clone and the rest were the South American plants as introduced.

All plants were propagated in the glasshouse. Adventitious shoots originating from internal layers of the plant were produced by disbudding tubers and are conveniently referred to as "deep shoots" (references and technique in Simmonds, I964).

\section{RESULTS}

\section{(i) Spectocle and splash}

All the four clones upon which this work is based share a common phenotype: they have a ground (cortex) colour plus a splash (periderm) pattern around the eyes, with or without spectacle and it is the variability of this last pattern that is of interest (plate). Spectacle results from failure of pigmentation, giving white eye patches on a coloured background. The genetic control of spectacle on a self-coloured ground in diploids is simple (Dodds and Long, 1956; Dodds and Paxman, 1962) but is more difficult to interpret in the tetraploids, in which spectacle and splash show complex and yet poorly understood interrelations (Howard, 1964).

\section{(ii) The behaviour of $62 / 191$}

Somatic segregation was first recognised in $62 / 191$ and the main features of the behaviour can all be illustrated by reference to this stock. Results are summarised in text-fig. 1 . The original tubers were pale pink plus a weak pink splash with or without spectacle and a descendent tuber was classified as spectacle $(s p t)$ if it bore any trace of the spectacle pattern, or as non-spt.

There are four points to make: (I) Spectacle was maintained at fair frequency only in the line maintained by growing spt tubers (text-fig I, top). (2) The non-spt line bred true throughout (text-fig. I, 


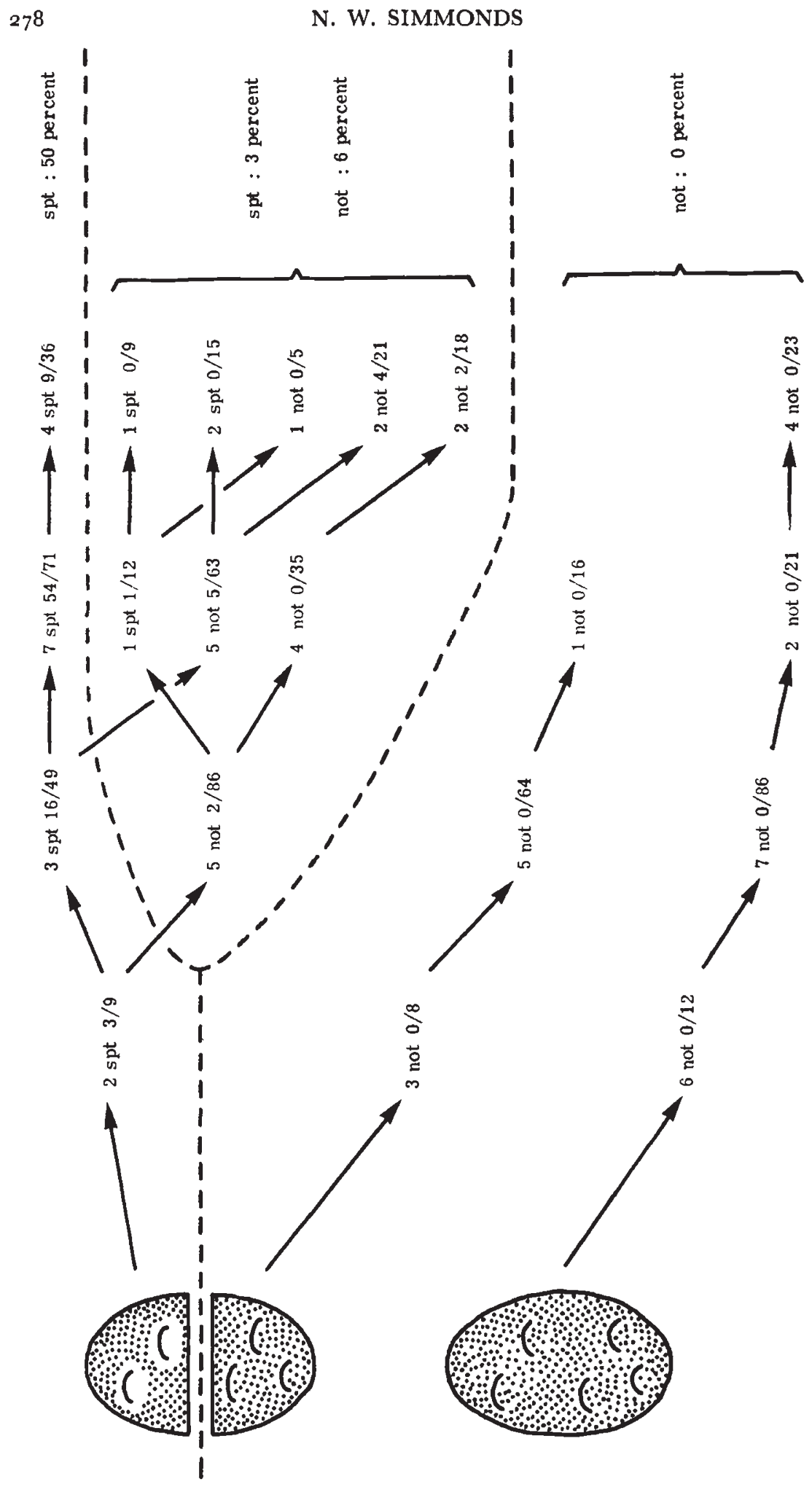

TEXT-FIG. 1.-The behaviour of spectacle in four vegetative generations of $62 / 191 . \quad$ Each entry gives the number of plants raised, the phenotype of the parent tubers, and the frequencies of spt/total tubers; at right, spt frequencies in spt, " mixed" and non-spt lines (see text). 
bottom) but the capacity to produce spectacles was not completely lost because a plant raised from a cutting in the third generation bore a spt tuber. (3) Segregation in the original spt tuber is apparent, the non-spt rose end producing a non-spt subline. (4) Spt frequency depends not only upon the phenotype of the mother tuber but also upon its breeding

TABLE

Vegetative progeny of plants showing variable spectacles. Spectacle tubers per cent. in progeny with, in brackets, numbers of plants and total tubers scored

\begin{tabular}{|c|c|c|c|}
\hline \multirow{2}{*}{ Stock } & \multirow{2}{*}{ Generation } & \multicolumn{2}{|c|}{$\begin{array}{l}\text { Tuber progeny of plants raised } \\
\text { from tubers that were }\end{array}$} \\
\hline & & non-spt & $s p t$ \\
\hline $62 / 191$ & $\begin{array}{c}1 \\
2 \\
3 \\
4 \\
\text { totals }\end{array}$ & $\begin{array}{l}\text { o }(9,20) \\
1 \quad(17,236) \\
4(12,135) \\
9(9,67) \\
3(47,458)\end{array}$ & $\begin{array}{l}33(2,9) \\
33(3,49) \\
66(8,83) \\
15(7,60) \\
4^{1}(20,201)\end{array}$ \\
\hline $62 / 231$ & $\begin{array}{c}1 \\
2 \\
3 \\
\text { total }\end{array}$ & $\begin{array}{c}o(1,4) \\
13(5,24) \\
o(6,27) \\
6(12,55)\end{array}$ & $\begin{array}{l}75(1,4) \\
89(3,18) \\
35(6,23) \\
60(10,45)\end{array}$ \\
\hline $62 / 232$ & $\begin{array}{c}1 \\
2 \\
3 \\
\text { totals }\end{array}$ & $\begin{array}{l}0(1,10) \\
o(2,8) \\
o(6,60) \\
0(9,78)\end{array}$ & $\begin{array}{l}100(3,27) \\
95(6,46) \\
82(7,57) \\
90(16,130)\end{array}$ \\
\hline $62 / 235$ & $\begin{array}{c}1 \\
2 \\
3 \\
\text { totals }\end{array}$ & $\begin{array}{l}24(3,42) \\
19(7,111) \\
39(10,131) \\
29(20,284)\end{array}$ & $\begin{array}{l}98(3,44) \\
54(11,159) \\
67(9,133) \\
65(23,336)\end{array}$ \\
\hline
\end{tabular}

history; thus the percentages on the right of text-fig. I represent $s p t$ frequencies over all generations of the spt line, the " mixed" lines in the middle of the figure (i.e. those propagated sometimes from spt, sometimes from non-spt tubers) and the two non-spt lines. It is clear that the occurrence of non-spt tubers in the intermediate ancestry of $s p t$ reduces the frequency of $s p t$ tubers and, contrariwise, that $s p t$ tubers in the ancestry of a non-spt tuber does the opposite.

(iii) Somatic segregotion in four clones

A survey of the Commonwealth Potato Collection Andigena and Chilean (tetraploid) stocks yielded some fifteen clones with promising phenotypes. Several failed to show the effect, others were virusinfected and others still were difficult to classify or otherwise unsatisfactory for experiment. Three remained and results for these, together with $62 / 191$ are summarised in table $I$. Conclusions are 
that: (I) All gave clear evidence of somatic segregation in that the phenotypes of progeny were correlated with those of parents. (2) There was considerable variation in $s p t$ frequencies between successive generations of one stock but no evident overall trend upwards or downwards. (3) Spectacle frequencies varied greatly between clones in both spt and non-spt lines. The clone $62 / 23^{2}$ provided the greatest contrast of all in that it covered the entire range of spectacle frequencies from o to about go per cent. (plate, table r). For simplicity the data of table I are classified only by phenotype of parental tuber and the effect of ancestry (revealed by 62/rgr) is therefore obscured. Breakdown of the pedigrees gave a series of comparisons of $s p t$ frequencies in $s p t$, "mixed" and non-spt lines, as on the right of text-fig. I (and see text above). Data for $62 / 23$ I and $62 / 232$ are too few to be meaningful; for $62 / 235$, results are similar to those for $62 / 191$, thus:

\begin{tabular}{|c|c|c|c|}
\hline \multirow{2}{*}{ non-spt line } & \multicolumn{2}{|c|}{ " mixed "lines } & $s p t$ line \\
\cline { 2 - 4 } & $s p t$ & non-spt & \\
\hline $\begin{array}{c}23 \text { per cent. } \\
(39 / 168)\end{array}$ & $\begin{array}{c}39 \text { per cent. } \\
(44 / 114)\end{array}$ & $\begin{array}{c}40 \text { per cent. } \\
(40 / 100)\end{array}$ & $\begin{array}{c}75 \text { per cent. } \\
(177 / 236)\end{array}$ \\
\hline
\end{tabular}

The data discussed so far are based on overall spt frequencies, a tuber being classified as spectacle if it showed unambiguous signs of the character in at least one eye. In all these materials there is, in fact, a great range of expression from a small incomplete spectacle visible as a streak below the eye or as a half-spectacle divided longitudinally, through one or a few complete spectacles (usually in the proximal part of the tuber) to the strongest expression in which every eye is spectacled and the distal end of the tuber is unpigmented (plate I). General observation showed that as overall spt frequencies changed in response to selection so the expression of the character altered, low frequencies being associated with weak expression, high with strong expression. This was very evident in 62/r91 and 62/235, less so in $62 / 231$ and $62 / 232$ in which the change of phenotype in either direction was rapid and relatively complete (table $\mathrm{I}$ ). The point is illustrated in table 2 by reference to the third generation of $62 / 235$. The expression of the character was very weak and the frequency of complete spectacles was low in plants derived from non-spt parent tubers, ligher in plants of mixed lines that had spt parents and higher still in the spt line itself. Thus both frequency and expression of the character show correlated change that depends upon ancestry.

In stocks such as these, the general trend of spectacle frequencies with time is obviously of interest. If the initial spt frequency in a stock is $Z_{0}$, the probability that a tuber from a plant raised from a $s p t$ tuber is also $s p t$ is $p$, and that one from a plant raised from a non-spt tuber 
is $s p t$ is $r$, then, under a system of random propagation, the frequency of spectacles, $\mathrm{Z}_{n}$, after $n$ generations is

$$
\mathrm{Z}_{n}=\frac{r}{\mathrm{I}+r-p}+(p-r)^{n}\left[\mathrm{Z}_{0}-\frac{r}{\mathrm{I}+r-p}\right]
$$

which is plotted in text-fig. 2 using the estimates of $p$ and $r$ averaged over generations given in table $\mathrm{I}$. The simplifying assumption has been made that phenotype depends upon parental phenotype alone. The results indicate that three stocks would effectively reach equilibrium $($ at $r(1+r-p))$ after four or five generations but that, in one case

TABLE 2

Classification of the third generation of 62/235. Column 3-overall frequency of tubers shouing any sign of spectacle; column 4-mean score of spt tubers only, incompletely spt eyes scared 1 , complete spt 3 ; column 5 - frequency of tubers having one or more complete $\mathrm{spt}$ ejes in relation to total spt tubers

\begin{tabular}{|c|c|c|c|c|c|}
\hline Material & & $\begin{array}{l}\text { Tubers } \\
\text { classified }\end{array}$ & $\begin{array}{l}\text { Spt } \\
\text { frequency } \\
\text { (per cent.) }\end{array}$ & $\begin{array}{l}\text { Spl } \\
\text { tubers } \\
\text { score }\end{array}$ & $\begin{array}{l}\text { Complete } \\
\text { silt } \\
\text { (per cent.) }\end{array}$ \\
\hline non-spt line & . & 31 & 32 & $2 \cdot 0$ & 10 \\
\hline mixed $\left\{\begin{array}{l}\text { non-spt parents. } \\
\text { lines }\end{array}\right.$ & . & $\begin{array}{r}100 \\
59\end{array}$ & $\begin{array}{l}43 \\
54\end{array}$ & $\begin{array}{l}1 \cdot 7 \\
6 \cdot 4\end{array}$ & $\begin{array}{r}5 \\
41\end{array}$ \\
\hline spt line. & • & 74 & $7^{6}$ & $I 3 \cdot I$ & 79 \\
\hline
\end{tabular}

$(62 / 232)$, equilibrium would be reached at $\mathrm{Z}=\mathrm{o}$ only after very many generations. Clearly, there is a possibility that apparently homogeneous splashed stocks are really splashed-spt clones which have lost their spectacles. All four stocks tend to equilibria at $\mathrm{Z}<0.5$ $($ i.e. $r<1-p)$ and the question obviously arises whether this is characteristic of all variable spectacle material or whether equilibria greater than 50 per cent. occur. Evidence (yet incomplete) from new material suggests that the higher equilibria do indeed exist.

\section{(iv) The effect of vegetative distance}

The original spt tuber of 62/19 I was dissected and the spt line derived from the spectacled proximal half; the non-spt distal half gave a non-spt line (text-fig. I). This suggests that the original tuber was heterogeneous and that the reproductive behaviour of a part was correlated with its phenotype. This was tested and found to be so (table 3). The distal (rose) end of the tuber continues growth after the proximal (heel) end is determined and these results therefore suggest that the change from spt to non-spt had occurred during the 
growth of the tubers chosen for experiment. On this basis, the more cell generations that elapse-the greater the "vegetative distance" from the parent tuber-the more likely is the change to occur. Two experiments with aerial stems support this view.

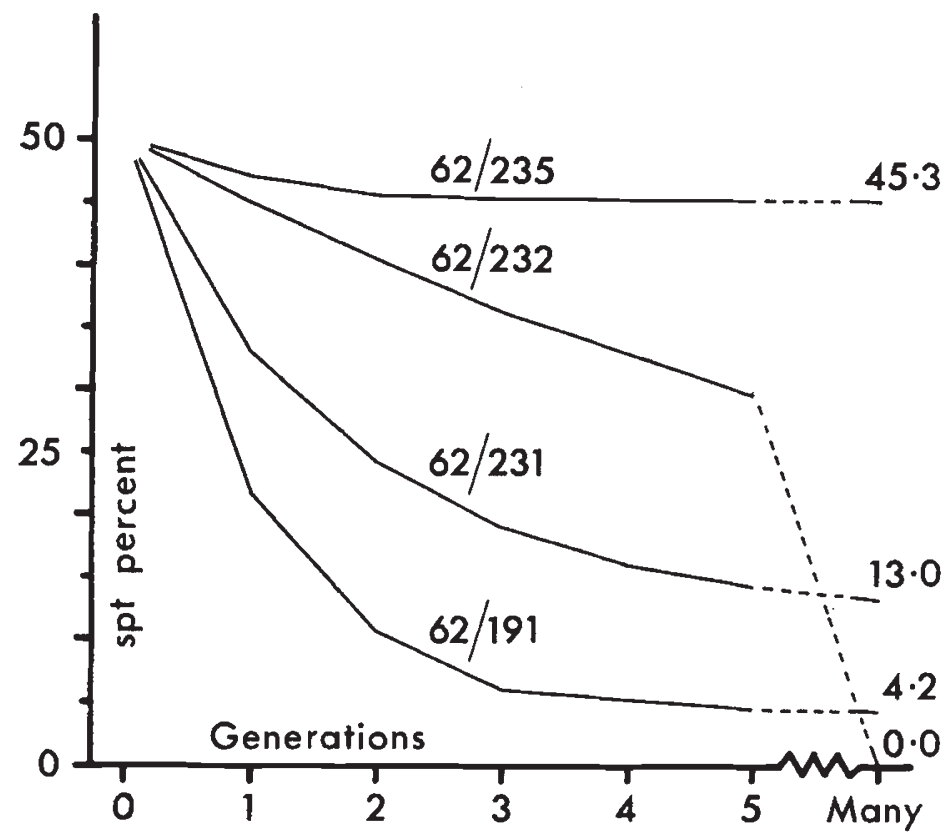

TEXT-FIG. 2.-Expected spectacle frequencies following generations of random propagation. The numbers on the right are equilibrium frequencies per cent.

TABLE 3

The effect of tuber dissection. Spectacle tubers per cent. with, in brackets, numbers of plants and total numbers of tubers scored

\begin{tabular}{|c|c|c|}
\hline \multirow{2}{*}{ Stock } & \multicolumn{2}{|c|}{ Tuber progeny of plants raised from } \\
\hline & spt proximal half & non-spt distal half \\
\hline $\begin{array}{l}62 / 231 \\
62 / 232 \\
62 / 235\end{array}$ & $\begin{array}{r}75(1,4) \\
100(3,36) \\
81(1,16)\end{array}$ & $\begin{array}{c}o(1,5) \\
6(2,16) \\
3^{8}(1,13)\end{array}$ \\
\hline Totals & $93(5,56)$ & $18(4,34)$ \\
\hline
\end{tabular}

In the first (1963), the whole aerial stems of $62 / \mathrm{r} 9 \mathrm{I}$ were dissected, two-node cuttings were raised and the tuber progeny of the resulting plants were classified. In the second experiment ( 1964$)$, cuttings were taken from the tips of well-grown plants of $62 / 191,232$ and 265 , sometimes also from as near the base as possible. Results are given in 
table 4 , in which the last column is the expected spectacle frequency at equilibrium (text-fig. 2). In general, there is a trend towards the equilibrium, spectacle frequencies tending to fall with increasing vegetative distance from $s p t$ tubers and to rise from non-spt tubers (except in 62/232 in which equilibrium is zero). The idea of the two opposed rates of change operating (though phenotypically unexpressed) through vegetative cell generations seems to fit the facts quite well. Since a daughter tuber is formed some 3-10 cm. away from the parent tuber but a tuber from a stem-tip plant is formed some $60-80 \mathrm{~cm}$. away, the latter is probably some ten times as many cells away from

TABLE 4

The effect of vegetative distance. Spectacle frequencies per cent. with, in brackets, numbers of plants raised and total tubers scored. For explanation of two entries for $62 / 19 I$ and last column, see text

\begin{tabular}{|c|c|c|c|c|c|}
\hline \multirow{2}{*}{ Stock } & \multirow{2}{*}{$\begin{array}{l}\text { Parental } \\
\text { tuber }\end{array}$} & \multirow{2}{*}{$\begin{array}{c}\text { Parental } \\
\text { performance }\end{array}$} & \multicolumn{2}{|c|}{ Cuttings } & \multirow{2}{*}{$\begin{array}{l}\text { Expected } \\
\text { equilibrium } \\
\text { per cent. }\end{array}$} \\
\hline & & & lower & upper & \\
\hline \multirow[t]{2}{*}{$62 / 191$} & $\begin{array}{l}\text { not } \\
\text { spt }\end{array}$ & $\begin{array}{l}0.0(8,52) \\
29(3,28)\end{array}$ & $\begin{array}{l}2 \cdot 9(22,69) \\
19(9,26)\end{array}$ & $\begin{array}{l}5 \cdot 4(16,37) \\
4 \cdot 3(13,23)\end{array}$ & $4 \cdot 2$ \\
\hline & $\begin{array}{l}\text { not } \\
\text { spt }\end{array}$ & $\begin{array}{l}1 \cdot 5(8,65) \\
53(2,19)\end{array}$ & - & $\begin{array}{l}3 \cdot 8(15,52) \\
0 \cdot 0(4,15)\end{array}$ & \\
\hline $62 / 232$ & $\begin{array}{l}\text { not } \\
\text { spt }\end{array}$ & $\begin{array}{l}0 \cdot 0(6,60) \\
83(7,57)\end{array}$ & $\begin{array}{l}0 \cdot 0(7,29) \\
74(7,34)\end{array}$ & $\begin{array}{l}0 \cdot 0(7,13) \\
3^{6}(7,14)\end{array}$ & 0.0 \\
\hline $62 / 235$ & $\begin{array}{l}\text { not } \\
\text { spt }\end{array}$ & $\begin{array}{l}39(3,52) \\
82\left(7, \begin{array}{ll}1 & 7\end{array}\right)\end{array}$ & - & $\begin{array}{l}7 \cdot 1(6,28) \\
73(12,33)\end{array}$ & \} $45 \cdot 3$ \\
\hline
\end{tabular}

the parent as the former or, say, three cell generations more distant. A relatively rapid approach to equilibrium would the more be expected and the observations do not disagree with this idea.

\section{(v) The effect of temperature}

In order to test the effect of temperature on the rate of somatic change, plants were grown in growth chambers under a 12 -hour day at constant temperatures of 15 and $25^{\circ} \mathrm{C}$. Plants of spt and non-spt $62 / 235$ were used; they were started in the glasshouse in long days and transferred to the chambers when stolons were appearing but before tuber initiation. Results (table 5) did not suggest that temperature had any effect on spectacle frequency.

\section{(vi) The effect of grafting}

Material of $62 / 235$ was used for an experiment on the effect of grafting. Plants were started from tubers of the appropriate phenotype 
and shoot-tips were exchanged when the main stems were $10-15 \mathrm{~cm}$. tall. Thereafter, all stock foliage was pruned off so that the tops of

\section{TABLE 5}

The effect of temperature on the expression of spectacle in 62/235. Spectacle tubers per cent., first the frequency of all spectacles, second of tubers bearing one or more perfect spectacles; in brackets, numbers of plants and total tubers scored

\begin{tabular}{|c|c|c|}
\hline Treatment & spt line & non-spt line \\
\hline $\begin{array}{l}\text { High }\left(25^{\circ} \text { C. }\right) \\
\text { Low }\left(15^{\circ} \text { C. }\right) \\
\text { Glasshouse }\end{array}$ & $\begin{array}{l}86 \cdot 9,71 \cdot 7(5,46) \\
91 \cdot 8,77 \cdot 0(5,48) \\
81 \cdot 5,63 \cdot 0(6,54)\end{array}$ & $\begin{array}{l}54 \cdot 8,2 \cdot 4(5,42) \\
34 \cdot 1,9 \cdot 5(4,44) \\
46 \cdot 8,10 \cdot 6(6,47)\end{array}$ \\
\hline
\end{tabular}

the plants were entirely scion. Results were as follows (total spt frequency per cent. with, in brackets, numbers of plants and tubers):

\begin{tabular}{|c|c|c|c|c|}
\hline \multicolumn{2}{|c|}{ Ungrafted controls } & \multicolumn{2}{|c|}{$s p t$ scion on } & non-spt scion \\
\hline spt & non-spt & $s p t$ & non-spt & on spt \\
\hline $\begin{array}{c}65 \\
(2,48)\end{array}$ & $\begin{array}{c}25 \\
(2,47)\end{array}$ & $\begin{array}{c}94 \\
(3,62)\end{array}$ & $\begin{array}{c}27 \\
(4,49)\end{array}$ & $\begin{array}{c}67 \\
(5,42)\end{array}$ \\
\hline
\end{tabular}

Grafts of non-spt on non-spt failed so the data are to this extent incomplete but the results, as they stand, do not suggest the existence of any graft-transmissible effect: the last two entries are very near to the control figures in the first two. The spt on spt frequency is, however, rather high and further experiments are planned.

\section{(vii) Expression in relation to meristem layers}

"Deep-shoot" plants raised from adventitious shoots derived from the inner layers of disbudded tubers were raised and their tubers classified, with the following results (spectacles per cent. with, in brackets, numbers of plants and total tubers):

$$
\begin{aligned}
& 62 / 191 \text { from non-spt tubers- }-92(13,72) \\
& 62 / 231 \text { from non-spt tubers-10o }(1,7) \\
& 62 / 235 \text { from non-spt tubers-72 }(3,58) .
\end{aligned}
$$

Average expected $s p t$ frequencies from untreated non-spt tubers are (table I): 62/19I-3, 62/23I-6, and 62/235-29 per cent. It is clear, therefore, that deep shoot plants show very greatly enhanced spectacle frequencies; indeed, all three frequencies given above exceed the normal expectations for materials of these stocks raised from spt tubers $(4 \mathrm{I}, 60$ and 65 per cent. respectively-table $I)$. Information is 
yet wanted on the behaviour of deep-shoot plants raised from spt tubers; what little there is (for 62/235) suggests very high spt frequencies. It is clear, at least, that tubers having the non-spt phenotype are heterogeneous; they are, in effect, chimeras in which the inner cell layers retain the capacity for spectacle expression.

Not all the spt tubers borne by deep-shoot plants could be confidently classified as to splash but some certainly and probably many were of the original ground-colour plus splash plus spectacle type. This observation and the perfectly clear imposition of spectacle on both underlying colours (e.g. plate I) jointly seem to disagree with Howard's (1964, fig. 2) interpretation of the results of eye-excision experiments.

\section{(viii) Breeding behoviour}

The clones 62/231, 232 and 235 all proved to be infertile and no breeding tests have so far been possible; $62 / \mathrm{Ig}$ I is fertile, however, and

TABLE 6

Selfed progeny of $62 / \mathrm{I} 9 \mathrm{I}$. $\chi^{2}[2]$ for parent tubers $=2 \cdot 7$, residual heterogeneity $\chi^{2}[4]=2 \cdot 8$

\begin{tabular}{|c|c|c|c|c|}
\hline \multicolumn{2}{|c|}{ Parent tuber } & $\begin{array}{l}\text { Pink and } \\
\text { splash }\end{array}$ & Spcctacle & White \\
\hline $\begin{array}{l}s p t \\
s p t\end{array}$ & : & $\begin{array}{l}45 \\
77\end{array}$ & $\begin{array}{l}17 \\
32\end{array}$ & $\begin{array}{r}10 \\
8\end{array}$ \\
\hline $\begin{array}{l}\text { non-spt } \\
\text { non-spt }\end{array}$ & : & $\begin{array}{l}59 \\
90\end{array}$ & $\begin{array}{l}16 \\
24\end{array}$ & $\begin{array}{r}8 \\
\text { I I }\end{array}$ \\
\hline Totals & . & $27 \mathrm{I}$ & 89 & 37 \\
\hline
\end{tabular}

four selfed progenies of plants raised from spectacle and non-spectacle tubers were compared (table 6). Classification of the non-spectacle pigmented plants was difficult and the first column of table 6 represents various shades of self-colour and splash. Many plants in the spectacle class were quite variable and the occurrence of some with very rare spectacles only and of others with very strong spectacles on a weakly coloured ground implies the possibility of occasional misclassification. Nevertheless the main conclusion is clear enough: all four families are (within the limits of classification) homogeneous and thus plants raised from $s p t$ and non-spt tubers bred similarly. The force of this conclusion must, however, be somewhat weakened by the fact that, as shown above, the spectacle-producing potentialities of the stem apex (where the flowers are borne) are not the same as those of the basal regions of the plant; failure to find a difference in sexual transmission must, by nature of the evidence, be indecisive. Further breeding tests with stocks which can be shown to retain the capacity 
to produce contrasted phenotypes at the stem apex are being undertaken (table 4).

\section{(ix) Other observations}

In comparison with diploids, the Andigena potatoes are in some ways inconvenient objects for experiment: they are often infertile and the genetical control of pigmentation is much less well understood. A start has therefore been made on the production of di-haploids from tetraploid variable-spectacle stocks. Concurrently, a search is being made among existing diploid materials for stocks which show the behaviour. Among scores of plants examined, no evidence has yet been found that significant variation in spectacle pattern occurs within a diploid clone. This statement applies to spectacles on a self-coloured ground; the splash pattern is rare in the diploids and, indeed, no definite examples of splash on a coloured ground have yet been seen. Since, as stated above (and see plate), the variable spectacle behaviour has so far been detected in tetraploids only in types with ground colour plus splash plus spectacle, it may be that the rarity of splash in the diploids is the cause of failure. The point is thus emphasised that somatic segregation is not a feature of spectacled potatoes at large but only of one particular kind of spectacle.

\section{CONCLUSIONS}

The following eight conclusions are suggested: (I) the behaviour is not rare and has been detected for certain in four clones coming from very widely separated localities in South America; (2) it occurs in new zygotes and old clones; (3) the main feature of the behaviour is a correlation between the phenotypes of parental and progeny tubers but qualified by an effect of ancestry such that the antecedents of the parental tuber also affect the behaviour of the progeny; (4) the statistical outcome of random propagation can be represented by considering two opposed frequencies of change and this leads to the expectation of equilibrium frequencies of spectacle which differ between clones and lie between o and nearly 50 per cent. (or possibly higher); (5) the evidence from dissection of tubers and aerial parts of plants suggests that the causal changes (whatever they may be) proceed during vegetative cell generations, spectacle frequencies moving up or down, as the case may be, towards an equilibrium; (6) the evidence from deep shoots shows that non-spectacle tubers are, in a sense, chimerical inasmuch as spectacles are recovered from the inside layers, though phenotypically absent from the outside; (7) there is no evidence that spectacle frequency is affected by external agencies such as temperature or grafting; and (8) whatever the agency that causes the phenotypic change, it either does not affect the germ layer or is not transmitted to sexual progeny, so that unlike phenotypes breed alike.

None of these conclusions points unambiguously towards an interpretation based either upon nuclear gene mutation or upon 

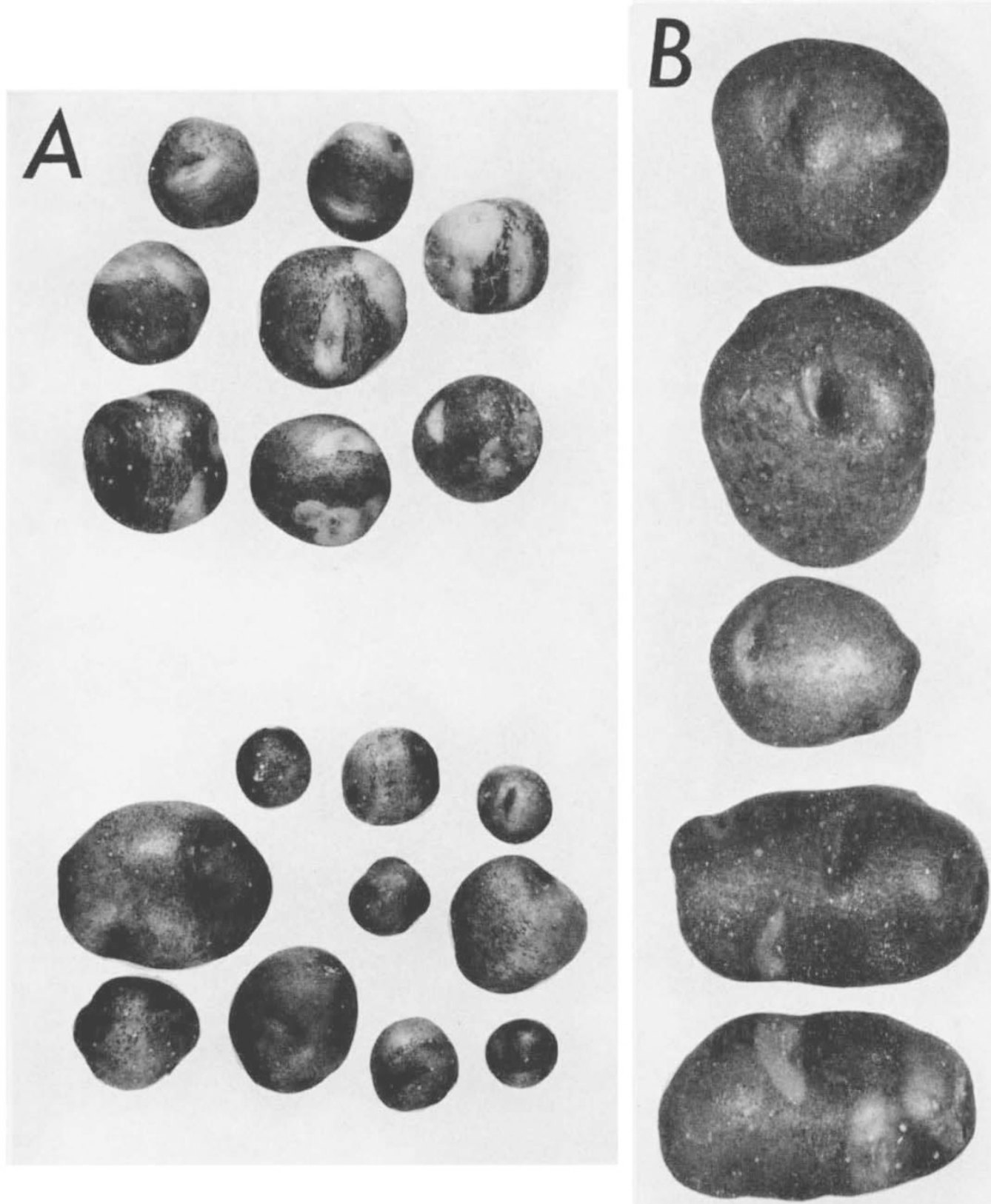

Plate I A.-The produce of two first-generation plants of 62/232 (table I); above, from a spt parent tuber, below from a non-spt tuber $(\times 0.8)$.

I B.--The expression of spectacle. One non-spt and two weakly spt tubers from $62 / 235$; one tuber of 62/23I strongly spt in the heel-end only; and one uber of 62-23I full spt in heel and rose ( $\times \mathrm{I} \cdot 6)$. 
control by cytoplasmic factors, though neither can be excluded. Since the change, whatever its cause, is expressed only in the outermost layer of the plant it is clear that failure of transmission to sexual descendants (apart, even, from the necessary qualifications expressed above) simply does not provide evidence upon which a choice between nuclear and cytoplasmic control could be based.

Nevertheless it seems worthwhile to draw attention to a rather striking analogy between the behaviour of spectacle and of certain proved cytoplasmic variants of Aspergillus glaucus (Jinks, I957; Mather and Jinks, 1958): in both organisms high and low somatic selection leads to phenotypic change followed by reversion towards equilibrium when selection is relaxed; and, in both again, sexual reproduction has a standardising effect such that unlike phenotypes breed alike.

Another analogy is provided by the class of behaviour referred to as Phase Change by Brink ( 1962 ) best typified in the regular succession of juvenile and adult morphology in many higher plants. There is one rather striking observation of phase change phenomena which suggests that the situation in potatoes may be related. This is an observation by Wellensiek (1952) to the effect that disbudded apples and pears produced knobs of deep-seated adventitious tissue on the stems and that these knobs ("sphaeroblasts") sometimes produced. adventitious shoots which, if they could be rooted, assumed the juvenile form of the tree. The juvenile phase persisted chimerically ${ }^{*}$ in the inner tissues of the mature phase just as the capacity to produce spectacles persisted in the inner tissues of the non-spt (or low-spt) lines of potatoes. Thus one might think of a change of frequency in certain (not all) potato spectacle genotypes as being a "normal" feature of development rather than as an "abnormal" behaviour to be investigated by conventional genetical techniques. In Brink's term they would be "paragenetic" in nature, leaving open the question of whether the immediate agent of change is nuclear or cytoplasmic.

The observation that deep-shoot plants from non-spectacled tubers may themselves bear spectacles is not new. Asseyeva (I931, recently confirmed by Howard, I964) found this to be true of what she called hidden-spotted tubers, i.e. tubers with ground cortex colour plus splash. Plants bearing only such tubers from the start (e.g. Howard's thirteen DEMR seedlings in family 35/68) might be regarded as variable spectacles in which $r$ and $p$ are both very small so that an equilibrium spectacle frequency of zero is attained at once and Howard's data on reversion to non-spectacle do not disagree with this idea. Contrariwise, the stocks picked for the present study were picked because they had at least some spectacles and selection of fairly high values of $p$ and $r$ was automatic. How one describes a clone may

* This seems certain for Wellensiek's fruit trees and it would be interesting to have similar observations for other plants. It does not follow that all persistent juvenile tissues of the mature plant are deeply seated and Brink's ( $I 962)$ review in fact makes it clear that dormant or adventitious meristems of whatever origin on the older parts of many woody plants are intrinsically juvenile. 
therefore depend upon what one happens to see on looking at it for the first time.

\section{SUMMARY}

Certain tetraploid potatoes $\left(2 n=4^{8}\right)$ show a spectacle pattcrn in which pigmentation is suppressed in sharply defined areas around the eyes; in some clones, spectacle is variable both in frequency and intensity of expression and the phenotypes of progeny tubers are correlated with those of the parent. Thus "somatic segregation" occurs, resulting in the differentiation of phenotypically distinct subclones in which spectacle frequencies may be maintained by selection at various levels between $o$ and about go per cent. There is no evidence that grafting or temperature affect spectacle frequency, nor that any phenotypic change is transmitted to sexual progeny. Adventitious deep shoots of sub-epidermal origin from non-spectacle tubers give plants that bear spectacle tubers in high frequency, showing that the parent is, in a sense, chimerical. Somatic segregation of the spectacle pattern thus seems to be an autonomous somatic behaviour which is expressed as a result of differentiation between cell laycrs at the growing point; it seems to have something in common with the Phase Change of Brink and thus may be a paragenetic phenomenon.

\section{REFERENCES}

AsSeYeVA, T. I931. Bud mutations in the potato. Bull. appl. Bot. Leningrail, 27, I35-2 I 7 .

BRINK, R. A. 1962. Phase change in higher plants and somatic cell heredity. Quart. Rev. Biol., 37, I-22.

DODDS, K. S., AND LONG, D. H. I956. The inheritance of colour in diploid potatocs. II. A three factor linkage group. 7. Genet., 54, 27-4I.

DODDS, K. S., AND PAXMAN, G. J. 1962. The genetic system of cultivated diploid potatoes. Evolution, 16 , I 54-167.

HOWARD, H. W. I964. Further effects of the pigment-restricting gene $M$ in potatocs: hidden spotted and spectacled. Heredity, rg, 349-356.

Jinks, J. L. 1957. Selection for cytoplasmic differences. Proc. Roy. Soc. B., 146 , 527-540

MATHER, K., AND JINKs, J. L. 1958. Cytoplasm in sexual reproduction. Nature, Lond., I82, I 188-1 190.

SIMmONDs, N. W. 1964. Observations on potato callus and adventitious shoot formation. Amer. Potato 7., 4I, 1 29-36.

WELLENSIEK, S. J. 1952. Rejuvenation of woody plants by formation of sphæroblasts. Kon. Nederl. Akad. Wetensch. Amsterdam, 55, 567-573. 